\title{
Effect of Trisodium Citrate on Rheological and Physical Properties and Microstructure of Yogurt
}

\author{
T. Ozcan-Yilsay, ${ }^{\star} †$ W.-J. Lee,†‡ D. Horne,§ and J. A. Lucey† \\ *Department of Food Engineering, Uludag University, 16059 Gorukle, Bursa, Turkey \\ †Department of Food Science, University of Wisconsin, 1605 Linden Drive, Madison 53706-1565 \\ $\ddagger$ Division of Animal Science and Technology, Gyeongsang National University, Jinju 660-701, South Korea \\ §Formerly of the Hannah Research Institute, Ayr, KA6 5HL, Scotland
}

\begin{abstract}
The effect of trisodium citrate (TSC) on the rheological and physical properties and microstructure of yogurt was investigated. Reconstituted skim milk was heated at $85^{\circ} \mathrm{C}$ for $30 \mathrm{~min}$, and various concentrations ( 5 to $40 \mathrm{mM}$ ) of TSC were added to the milk, which was then readjusted to $\mathrm{pH}$ 6.50. Milk was inoculated with $2 \%$ yogurt culture and incubated at $42^{\circ} \mathrm{C}$ until $\mathrm{pH}$ was 4.6. Acid-base titration was used to determine changes in the state of colloidal calcium phosphate (CCP) in milk. Total and soluble Ca contents of the milk were determined. The storage modulus $\left(\mathrm{G}^{\prime}\right)$ and loss tangent (LT) values of yogurts were measured as a function of $\mathrm{pH}$ using dynamic oscillatory rheology. Large deformation rheological properties were also measured. Microstructure of yogurt was observed using confocal scanning laser microscopy, and whey separation was also determined. Addition of TSC reduced casein-bound $\mathrm{Ca}$ and increased the solubilization of CCP. The $\mathrm{G}^{\prime}$ value of gels significantly increased with addition of low levels of TSC, and highest $G^{\prime}$ values were observed in samples with 10 to $20 \mathrm{~m} M$ TSC; higher ( $>20 \mathrm{mM}$ ) TSC concentrations resulted in a large decrease in $G^{\prime}$ values. The LT of yogurts increased after gelation to attain a maximum at $\mathrm{pH} \sim 5.1$, but no maximum was observed in yogurts made with $\geq 25 \mathrm{~m} M$ of TSC because CCP was completely dissolved prior to gelation. Partial removal of CCP resulted in an increase in the LT value at $\mathrm{pH}$ 5.1. At low TSC levels, the removal of CCP crosslinks may have facilitated greater rearrangement and molecular mobility of the micelle structure, which may have helped to increase $G^{\prime}$ and LT values of gels by increasing the formation of crosslinks between strands. At high TSC concentrations the micelles were completely disrupted and CCP crosslinks were dissolved, both of which resulted in very weak yogurt gels with large pores obvious
\end{abstract}

Received August 16, 2006.

Accepted December 4, 2006

${ }^{1}$ Corresponding author: jalucey@facstaff.wisc.edu in confocal micrographs. Gelation $\mathrm{pH}$ and yield stress significantly decreased with the use of high TSC levels. Lowest whey separation levels were observed in yogurt made with $20 \mathrm{mM}$ TSC, and whey separation greatly increased at $>25 \mathrm{~m} M$ TSC. In conclusion, low concentrations of TSC improved several important yogurt characteristics, whereas the use of levels that disrupted casein micelles resulted in poor gel properties. We also conclude that the LT maximum observed in yogurts made from heated milk is due to the presence of CCP because the modification of the CCP content altered this peak and the removal of CCP eliminates this feature in the LT profiles.

Key words: yogurt, trisodium citrate, rheology, microstructure

\section{INTRODUCTION}

Yogurt is produced by fermentation of milk with the thermophilic homofermentative lactic acid bacteria Streptococcus thermophilus and Lactobacillus delbrueckii ssp. bulgaricus. Yogurt is an important functional dairy product whose technological characteristics have been the subject of numerous investigations (Tamime and Robinson, 1999; Chandan et al., 2006; Tamime, 2006). There have been many studies on the rheological and physical properties of set yogurt (e.g., Kristo et al., 2003; Lee and Lucey 2004a,b; Raphaelides and Gioldasi, 2004).

It is well known that minerals play an important role in the structure and stability of casein micelles (Walstra, 1990; Horne, 1998). The minerals and caseins in milk are in dynamic equilibrium; small alterations in the distribution of Ca phosphate between the soluble and insoluble phases can lead to important effects on micellar stability. The state of caseins and minerals in milk is affected by $\mathrm{pH}$, temperature, and addition of Cachelating agents (De la Fuente, 1998; Augustin, 2000; Udabage et al., 2000; Gaucheron, 2005).

The impact of Ca-chelating agents, such as citrate or EDTA, on some properties of milk has been investigated 
(Munyua and Larsson-Raznikiewicz, 1980; Ward et al., 1997; Udabage et al., 2000). The Ca-chelating agents disrupt the casein micelles by reducing the $\left[\mathrm{Ca}^{2+}\right]$ and colloidal Ca phosphate (CCP) contents (Munyua and Larsson-Raznikiewicz, 1980; Fox and Mulvihill, 1982; Visser et al., 1986; Goddard and Augustin, 1995; Udabage et al., 2000), which causes casein micelle dissociation (Morr, 1967; Mohammad and Fox, 1983; Gaucheron 2005).

Lin et al. (1972) reported that removal of subcritical amounts of $\mathrm{Ca}^{2+}$ with EDTA, and other Ca-chelating agents, caused partial dissociation of casein micelles and the release of some soluble casein (mostly $\beta$ - and $\kappa$-casein). Further removal of $\mathrm{Ca}^{2+}$ from casein micelles with higher concentrations of EDTA $(0.9 \mathrm{mM} / 100 \mathrm{~mL})$ destroyed the micellar framework. Griffin et al. (1988) used EDTA (3.2 to $20 \mathrm{mM}$ ) as a Ca-chelating agent and reported that when the Ca-chelating agent concentration increased, it was not possible to remove significant amounts of $\mathrm{Ca}^{2+}$ without some micellar disaggregation. Udabage et al. (2000) found that adding high amounts of citrate and EDTA ( $20 \mathrm{~m} M / \mathrm{kg}$ of milk) resulted in a significant reduction in micelle diameter and a very large reduction in scattering density.

The addition of Ca-chelating agents to milk has been reported to increase firmness of acid gels made with glucono- $\delta$-lactone (GDL; Johnston and Murphy, 1992). Addition of EDTA also caused an increase in the loss tangent (LT) values in acid-heat-induced skim milk gels (Goddard and Augustin, 1995). Udabage et al. (2001) also investigated the effects of mineral salts and calcium chelating agents on the gelation of renneted skim milk. They found that depending on the level of chelating agent, addition of citrate or EDTA reduced the storage modulus $\left(\mathbf{G}^{\prime}\right)$ and above a certain concentration rennet gelation was completely inhibited $(10 \mathrm{mM} / \mathrm{kg}$ of milk).

However, there does not appear to be any information on impact of removal of various amounts of $\mathrm{CCP}$ on the gelation characteristics of yogurts. The objectives of this study were to determine the effect of addition of trisodium citrate (TSC) on the physicochemical properties of milk and to relate the resultant removal of CCP to the gelation process and the rheological properties and microstructure of yogurt gels made from these TSCtreated milks.

\section{MATERIALS AND METHODS}

\section{Materials}

Low heat skim milk powder with $6.60 \mathrm{mg} / \mathrm{g}(\mathrm{wt} / \mathrm{wt})$ of undenatured whey protein nitrogen (Bradley et al., 1992) was obtained from Dairy Farmers of America (Fresno, CA). Yogurt starter culture (YC-087, which contains Streptococcus thermophilus and Lactobacillus delbrueckii ssp. bulgaricus) was obtained from Chr. Hansen, Inc. (Milwaukee, WI). Trisodium citrate dihydrate was supplied by Sigma-Aldrich (St. Louis, MO).

\section{Preparation of Milk Samples}

Reconstituted skim milk (10.7\% wt/vol) was preheated at $85^{\circ} \mathrm{C}$ for $30 \mathrm{~min}$ and then cooled rapidly to $\sim 4^{\circ} \mathrm{C}$. Some milk samples were used for chemical analysis; $0.02 \%(\mathrm{wt} / \mathrm{wt})$ sodium azide was added to these samples to prevent bacterial growth. Trisodium citrate was added to milk at various concentrations $(5,10,20$, 25,30 , and $40 \mathrm{mM}$ ) by slow addition with continuous stirring. The $\mathrm{pH}$ was then adjusted by drop-wise addition of $1 \mathrm{~N} \mathrm{HCl}$ to a final $\mathrm{pH}$ of $6.50 \pm 0.02$ at $25^{\circ} \mathrm{C}$. Milks were stirred for $2 \mathrm{~h}$ until the $\mathrm{pH}$ was constant and also readjusted if necessary. Starter culture was prepared using the method described by Lee and Lucey (2004a). For yogurt fermentation, milk was warmed to $42^{\circ} \mathrm{C}$ before inoculation in a water bath and inoculated with $2 \%$ (wt/wt) working culture. Starter cultures were added to the flasks under aseptic conditions to try to avoid contamination.

\section{Acid-Base Buffering Properties}

Buffering curves of milks containing different levels of TSC were determined by the acid-base buffering method described by Lucey et al. (1993). Milks were titrated from its initial $\mathrm{pH}$ to 3.0 with $0.5 \mathrm{~N} \mathrm{HCl}$ and then from $\mathrm{pH} 3.0$ to 8.0 with $0.5 \mathrm{~N} \mathrm{NaOH}$ by using a Mettler Toledo DL DL50 Autotitrator (Mettler Toledo, Greifensee, Switzerland). Buffering curves were prepared by plotting the buffering index as a function of $\mathrm{pH}$.

\section{Ca Analysis}

The Ca contents of milk and ultrafiltration (UF) permeate were determined using inductively coupled plasma-optical emission spectrometry (Vista-MPX Simultaneous ICP-OES, Varian Inc., Palo Alto, CA). Wavelength used for Ca analysis was $317.9 \mathrm{~nm}$ (Park, 2000). Skim milks preheated at $85^{\circ} \mathrm{C}$ for $30 \mathrm{~min}$ and various concentrations of TSC $(0,5,10,15,20,25,30$, or $40 \mathrm{~m} M$ ) were added. The $\mathrm{pH}$ was adjusted to 6.5 and milk was held for $2 \mathrm{~h}$ and the $\mathrm{pH}$ rechecked and readjusted if necessary. Ultrafiltration permeates of skim milks treated with TSC were obtained using a Prep/Scale-TFF membrane (Millipore, Billerica, MA), which had a 10-kDa molecular weight cut-off (Mizuno and Lucey, 2005). Casein-bound Ca was calculated using the following equation (White and Davies, 1958): 
Casein-bound $\mathrm{Ca}=$ Total $\mathrm{Ca}-\mathrm{Ca}$ in UF permeate.

\section{Rheological Properties}

Yogurt gel formation was determined using a Universal Dynamic Spectrometer (Paar Physica UDS 200 controlled stress rheometer, Physica Messtechnik GmbH, D-70567 Stuttgart, Germany) with the measurement of $\mathrm{G}^{\prime}$ and LT (ratio of loss to storage modulus). A profiled cup and bob measuring geometry was used. The cup and bob measuring geometry consisted of 2 coaxial cylinders (inner diameter $25 \mathrm{~mm}$; outer diameter $27.5 \mathrm{~mm}$ ). Fourteen milliliters of preheated milk was inoculated with $2 \%$ (wt/wt) starter culture and transferred to the rheometer. To prevent evaporation, a few drops of vegetable oil were added to the surface of milk. Yogurts were oscillated at a frequency of $0.1 \mathrm{~Hz}$ and with an applied strain of $1 \%$. Measurements were taken every $5 \mathrm{~min}$ until $\mathrm{pH}$ of 4.6 was reached. Gelation was arbitrarily defined as the point when the $\mathrm{G}^{\prime}$ of gels was greater than $1 \mathrm{~Pa}$ (Lucey et al., 1997b). The large deformation properties of yogurt gels formed in situ were determined by applying a single, constant shear rate $\left(0.01 \mathrm{~s}^{-1}\right)$ up to the yielding of gel. Yield stress $\left(\sigma_{\text {yield }}\right)$ was defined as the point when shear stress started to decrease. Yield strain $\left(\gamma_{\text {strain }}\right)$ was the strain value at the yield point (Lucey et al., 1997b).

\section{Whey Separation}

Whey separation was determined using the method described by Lucey et al. (1998a). Skim milk was preheated at $85^{\circ} \mathrm{C}$ for $30 \mathrm{~min}$ and then cooled rapidly with ice water. Before the inoculation with starter culture, the milk was warmed to $42^{\circ} \mathrm{C}$ in a water bath and inoculated with $2 \%$ (wt/wt) working culture. Then 220 $\mathrm{g}$ of inoculated milk was transferred to a $250-\mathrm{mL}$ volumetric flask and incubated at $42^{\circ} \mathrm{C}$ until $\mathrm{pH}$ of milk reached 4.6. Eight flasks were used for each treatment. The degree of whey separation was calculated as a percentage of the total weight of milk.

\section{Microstructure}

The microstructure of yogurt gels at $\mathrm{pH} 4.6$ was observed using confocal scanning laser microscopy operated in fluorescence mode according to the method described by Lee and Lucey (2004b). Preheat treated skim milks were mixed with TSC and then adjusted to $\mathrm{pH}$ 6.5 with $1 \mathrm{~N} \mathrm{HCl}$. Fifty milliliters of skim milk were inoculated with $2 \%$ (wt/wt) working starter culture and then mixed with $350 \mu \mathrm{L}$ of acridine orange [0.2\% (wt/ wt; Sigma Chemical Co., St Louis, MO], which is a fluorescent protein dye. The mixture was transferred to a slide with a cavity and then incubated at $42^{\circ} \mathrm{C}$ in a temperature-controlled incubator (model 650F, Fisher Scientific, Hanover, IL) until the $\mathrm{pH}$ of milk reached 4.6. A BioRad MRC 1024 confocal scanning laser microscope (Hemel Hempstead, UK), which had an aircooled $\mathrm{Ar} / \mathrm{Kr}$ laser with an excitation wavelength of 488 $\mathrm{nm}$, was used to investigate yogurt gels at the end of fermentation. Several fields (at least 5) were observed with a $60 \times$ oil immersion objective lens (numerical aperture $=1.4$ ), and representative micrographs were reported.

\section{Statistical Analysis}

Experimental data were tested by ANOVA and significance was indicated by $P<0.05$, using the statistical software SAS (version 8.02, SAS Institute Inc., Cary, NC). Each experiment was repeated 4 times.

\section{RESULTS AND DISCUSSION}

\section{Acid-Base Titration and Ca Analysis}

Changes in the CCP content of milk can be inferred from the acid-base buffering properties of milk (Lucey et al., 1996). The acid-base buffering curves for milk samples with different levels of added TSC are shown in Figure 1. The buffering peak at $\sim 5.1$ during acid titration of milk is caused by the solubilization of CCP, and the peak at $\mathrm{pH} \sim 6$ during base titration is due to precipitation of Ca phosphate (Lucey et al., 1993; Figure 1a). Milks containing $\geq 20 \mathrm{mM}$ TSC (Figures $1 \mathrm{~d}$ to g) did not have a buffering peak at $\mathrm{pH} \sim 5.1$ during acid titration or at $\mathrm{pH} \sim 6$ during base titration. This suggests that $\geq 20 \mathrm{~m} M$ TSC probably dissolved all CCP. Similar results were recently observed by Mizuno and Lucey (2005) for milk protein concentrate solutions at $\mathrm{pH}$ 5.8. Solubilization of CCP in milk occurs during acidification especially below $\mathrm{pH} 5.6$ and is complete by $\mathrm{pH} \sim 5.1$ (van Hooydonk et al., 1986; Dalgleish and Law, 1989; Lucey et al., 1996). Addition of TSC to milks resulted in an increase in soluble Ca (Table 1). The increase in soluble $\mathrm{Ca}$ is due to the solubilization of CCP. These results are also in agreement with those recently reported by Mizuno and Lucey (2005).

\section{Rheological Properties of Yogurt}

The effects of TSC on the rheological and physical properties of yogurt are summarized in Table 1. The addition of $\geq 20 \mathrm{mM}$ TSC to the milk resulted in a significant $(P<0.05)$ decrease in the gelation $\mathrm{pH}$, which became similar to the gelation $\mathrm{pH}(\sim 4.9$ to 5.0$)$ of unheated milk. The reduction in the gelation $\mathrm{pH}$ with high levels of TSC ( $\geq 20 \mathrm{mM})$ could be due to the disruption 


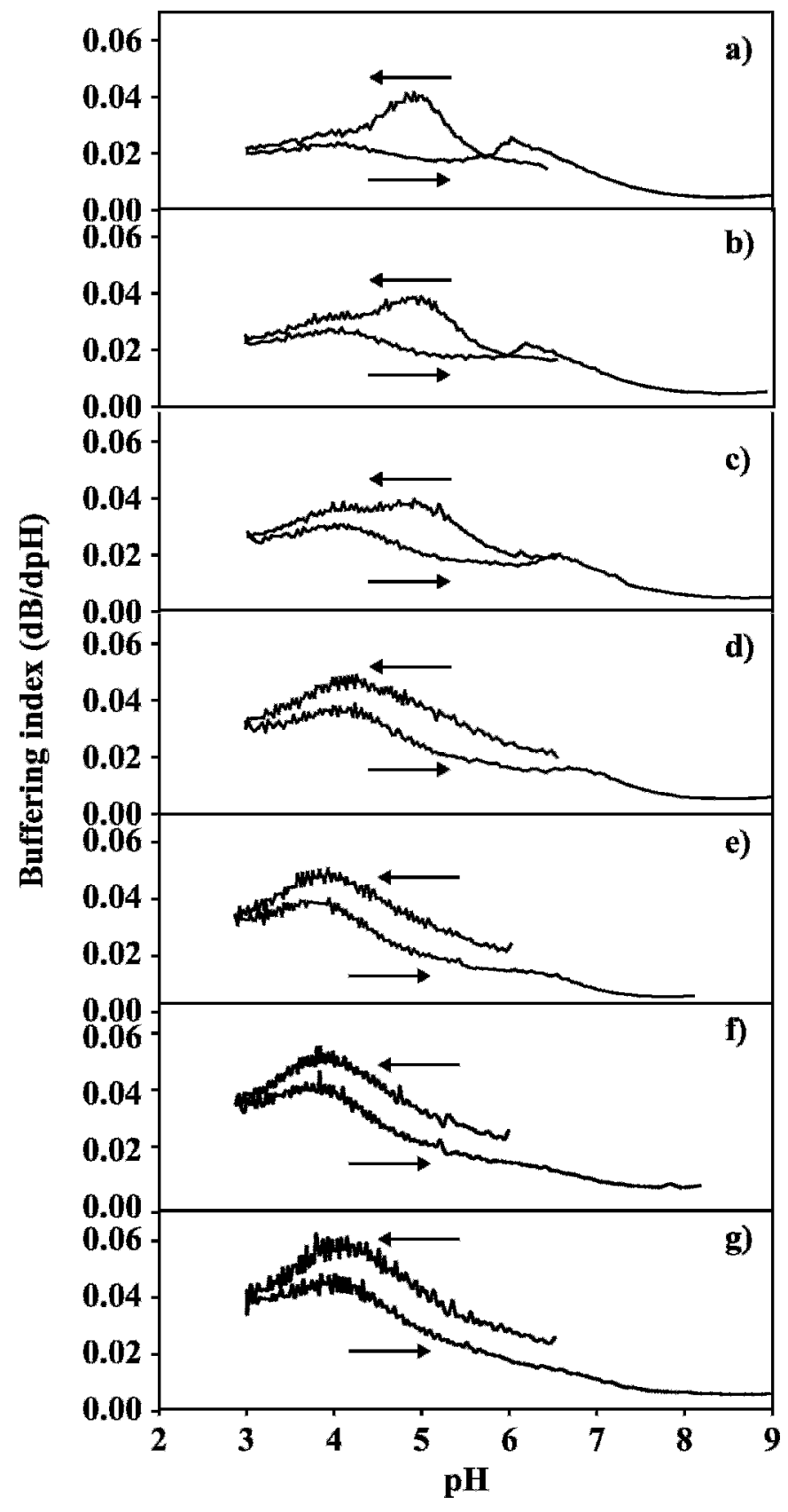

Figure 1. Acid-base buffering curves of milks containing different levels of trisodium citrate (TSC): a) 0, b) 5, c) 10, d) 20, e) 25, f) 30 , and g) $40 \mathrm{~m} M$ TSC (arrows indicate direction of titration).

of the original micelle structure, which in heated milk contains denatured whey proteins on the micelle surface (Lucey et al., 1997a). The higher isoelectric point of the main whey protein, $\beta$-LG, is involved in increasing the gelation $\mathrm{pH}$ of yogurt to $\sim 5.3$ compared with a gelation $\mathrm{pH}$ of $\sim 5$ in yogurts made from unheated milk (Lucey et al., 1998c). The addition of high concentrations of TSC to heat-treated micelles disrupted the mi- celles into smaller particles as indicated by the reduction in turbidity (Mizuno and Lucey, 2005). It is possible that these disrupted (smaller) particles had a surface that was largely dominated by newly exposed casein residues, and as a result the gelation $\mathrm{pH}$ was less dominated by the presence of denatured whey proteins. The gelation $\mathrm{pH}$ for acid gels made from sodium caseinate, which is a soluble and nonmicellar casein material, is approximately $\sim 4.9$ (Lucey et al., 1997b). The gelation time of yogurt, significantly $(P<0.05)$ increased with addition of $\leq 20 \mathrm{mM}$ TSC due to reduction in the gelation $\mathrm{pH}$.

The rheological properties of yogurts made with TSC are shown in Figure 2. The $\mathrm{G}^{\prime}$ profiles for gels made with 0,5 , and $10 \mathrm{~m} M$ TSC initially appeared to be similar, but at $\mathrm{pH}$ values $<5.0, \mathrm{G}^{\prime}$ increased at a faster rate in gels made with $10 \mathrm{~m} M$ TSC compared with gels made with 0 or $5 \mathrm{~m} M$ TSC (Figure 2a). Gels made with $20 \mathrm{~m} M$ TSC had a significantly lower gelation $\mathrm{pH}$ (Table 1 ), but after gelation they had a faster rate of increase in $\mathrm{G}^{\prime}$, such that by $\mathrm{pH}<5.0$ it had surpassed the $\mathrm{G}^{\prime}$ values for gels made with 0 or $5 \mathrm{mM}$ TSC. Addition of TSC had a significant effect $(P<0.05)$ on $\mathrm{G}^{\prime}$ values at $\mathrm{pH}$ 4.6; gels made with 10 and $20 \mathrm{mM}$ TSC had the highest $G^{\prime}$ values (Table 1). It appeared that some disruption of the micelle by limited levels of TSC improved the stiffness of yogurt gels. This effect is not a direct effect because the loss of CCP removes crosslinking material within casein particles, which should decrease gel stiffness. The removal of CCP results in an increase in LT, which increased the molecular flexibility of the caseins, and this may have enhanced the formation of crosslinks between casein particles and strands. Very high TSC concentrations $(>20 \mathrm{mM}$ ) resulted in yogurts with a lower $\mathrm{G}^{\prime}$ values at $\mathrm{pH} 4.6$ compared with yogurt made from milk without TSC. The $\mathrm{G}^{\prime}$ value of gels is related to the number, strength, or both of bonds between casein particles and the spatial distribution of strands of casein in the network (Zoon et al., 1988; Esteves et al., 2003). When CCP is dissolved within casein particles, there is a reduction in the number of CCP crosslinks and possibly an increase in electrostatic repulsion between the exposed phosphoserine residues (Lucey, 2002). Both of these effects may contribute to the reduction in the $G^{\prime}$ values in yogurt gels made from milk with high TSC levels.

The LT profiles as a function of $\mathrm{pH}$ for yogurts are shown in Figure 2b. In yogurt gels made from heated milk without TSC or milk with low TSC concentrations $(\leq 20 \mathrm{mM})$, a maximum in $\mathrm{LT}$ was observed at $\mathrm{pH} \sim 5.1$. The appearance of a maximum in LT is in agreement with previous studies of yogurts made from heated milk (e.g., Lee and Lucey, 2004a,b). Gels made with high TSC levels $(\geq 20 \mathrm{mM}$ ) had no maximum in LT. Before 
Table 1. Effects of trisodium citrate (TSC) on the Ca equilibrium in milk and the rheological and physical properties of yogurt made from TSC-treated milks ${ }^{1}$

\begin{tabular}{lccccccc}
\hline $\begin{array}{l}\text { TSC } \\
(\mathrm{m} M)\end{array}$ & $\begin{array}{c}\text { Gelation } \\
\text { time } \\
(\mathrm{min})^{2}\end{array}$ & $\begin{array}{c}\mathrm{pH} \text { at } \\
\text { gelation }\end{array}$ & $\begin{array}{c}\mathrm{G}^{\prime} \text { at } \\
\mathrm{pH} 4.6^{3} \\
(\mathrm{~Pa})\end{array}$ & $\begin{array}{c}\sigma_{\text {yield }}{ }^{2} \\
(\mathrm{~Pa})\end{array}$ & $\begin{array}{c}\gamma_{\text {yield }}{ }^{3} \\
(-)\end{array}$ & $\begin{array}{c}\text { Soluble Ca } \\
(\mathrm{mg} / 100 \mathrm{~g} \\
\text { of milk) }\end{array}$ & $\begin{array}{c}\text { Casein-bound } \\
\text { Ca (mg/100 g } \\
\text { of milk) }\end{array}$ \\
\hline 0 & $138^{\mathrm{d}}$ & $5.34^{\mathrm{a}}$ & $143^{\mathrm{c}}$ & $48^{\mathrm{b}}$ & $0.53^{\mathrm{ab}}$ & $29.0^{\mathrm{f}}$ & $70.4^{\mathrm{a}}$ \\
5 & $140^{\mathrm{d}}$ & $5.26^{\mathrm{a}}$ & $170^{\mathrm{b}}$ & $51^{\mathrm{b}}$ & $0.51^{\mathrm{abc}}$ & $38.4^{\mathrm{e}}$ & $61.0^{\mathrm{b}}$ \\
10 & $138^{\mathrm{d}}$ & $5.30^{\mathrm{a}}$ & $209^{\mathrm{a}}$ & $75^{\mathrm{a}}$ & $0.56^{\mathrm{a}}$ & $46.4^{\mathrm{d}}$ & $53.0^{\mathrm{c}}$ \\
20 & $158^{\mathrm{c}}$ & $5.12^{\mathrm{b}}$ & $191^{\mathrm{ab}}$ & $44^{\mathrm{bc}}$ & $0.44^{\mathrm{bcd}}$ & $64.7^{\mathrm{c}}$ & $34.7^{\mathrm{d}}$ \\
25 & $166^{\mathrm{bc}}$ & $5.04^{\mathrm{bc}}$ & $115^{\mathrm{d}}$ & $33^{\mathrm{c}}$ & $0.41^{\mathrm{d}}$ & $74.9^{\mathrm{b}}$ & $24.5^{\mathrm{e}}$ \\
30 & $169^{\mathrm{b}}$ & $4.99^{\mathrm{c}}$ & $85^{\mathrm{e}}$ & $16^{\mathrm{d}}$ & $0.37^{\mathrm{d}}$ & $75.7^{\mathrm{b}}$ & $23.7^{\mathrm{e}}$ \\
40 & $190^{\mathrm{a}}$ & $4.89^{\mathrm{d}}$ & $22^{\mathrm{f}}$ & $6^{\mathrm{d}}$ & $0.44^{\mathrm{cd}}$ & $91.3^{\mathrm{a}}$ & $8.1^{\mathrm{f}}$ \\
\hline
\end{tabular}

${ }^{1}$ Means of quadruplicate values and different letters in the same column are significantly different $(P<$ $0.05)$.

${ }^{2}$ Gelation was defined as the point when gels had a storage modulus $\geq 1 \mathrm{~Pa}$.

${ }^{3}$ Storage modulus, $\left(\mathrm{G}^{\prime}\right)$; yield stress, $\sigma_{\text {yield }}$; strain value at yielding, $\gamma_{\text {strain }}$.

the maximum in LT, an initial increase in LT has been observed in yogurt gels (e.g., Lee and Lucey, 2004a,b). This increase in LT could be due to a loosening of the intermolecular forces in casein particles resulted from the solubilization of CCP (Lucey, 2002; Lee and Lucey, 2004b). There was a clear relationship between the CCP content of micelles and the loss tangent value at $\mathrm{pH}$ 5.1 during yogurt gelation (Figure 3). The loss of low levels of Ca from micelles had no impact on the LT value at $\mathrm{pH} 5.1$, but as the loss of $\mathrm{Ca}$ increased there was a large increase in the LT value (Figure 3). High $\mathrm{LT}$ values may indicate that there may be an increased possibility of relaxation of bonds in network (van Vliet et al., 1991; Lucey, 2002). However, when yogurt gels were made from milk with high levels of TSC $(\geq 20 \mathrm{mM})$, almost all CCP was probably dissolved prior to gelation as indicated by the absence of the buffering peak at $\mathrm{pH}$ $\sim 5.1$ (Figure 1d to g) and the large increase in soluble calcium (Table 1). The solubilization of CCP removes the CCP crosslinks and weakens the protein-protein interactions inside casein particles, which is probably responsible for the absence of the maximum in LT after gelation (because the CCP was dissolved prior to gelation) and the higher LT values for these gels. Greater solubilization of CCP prior to gelation results in a network with a more viscous character (Figure 3 ).

The $\mathrm{G}^{\prime}$ and $\sigma_{\text {yield }}$ significantly increased with the addition of low concentrations of TSC, but they were reduced by high levels of TSC (Table 1). Johnston and Murphy (1992) investigated the effects of adding various types of calcium chelating agents on the physical properties of acid-set milk gels made using GDL. Increases in the apparent shear modulus (from penetration test) and also increases in the force required to break were observed in gels containing up to $30 \mathrm{~m} M$ disodium citrate. Johnston and Murphy (1992) did not observe a decrease in gel properties with the use of up to $30 \mathrm{~m} M$ disodium citrate; however, they did observe a decrease with the use of $>25 \mathrm{~m} M$ EDTA or $>5-8 \mathrm{~m} M$ hexametaphosphate. This presumably reflects differences in the ability of these agents to chelate $\mathrm{Ca}$ and also to disperse the casein micelles. Other possible reasons for the differences in the trends between our study and that of Johnston and Murphy (1992) include the use of GDL in the previous study because GDL binds some calcium and has a different acidification profile compared with yogurt fermentation (Lucey et al., 1998b) and the different gelation temperature $\left(20^{\circ} \mathrm{C}\right.$ for the previous study and $42^{\circ} \mathrm{C}$ in the present study).

The addition of $30 \mathrm{~m} M$ oxalate, EDTA, or citrate to milks resulted in a high proportion of nonsedimentable casein (Johnston and Murphy, 1992). Increased conformational mobility was observed when $\mathrm{Ca}^{2+}$ was chelated by EDTA, which would allow greater interpenetration of protein chains and improved opportunities for interactions in the structure. They concluded that the controlled disintegration of casein micelles produced by the addition of some low concentrations of Ca-chelating agents resulted in improvements in the properties of GDL-induced gels.

Goddard and Augustin (1995) reported on the effects of $\mathrm{pH}$ and added salts or chelating agents on the gel strength and dynamic rheological properties of acidheat induced gels made from reconstituted skim milk with GDL. Gel characteristics were affected by addition of salts or chelating agents, but each of their effects was different, depending on the final $\mathrm{pH}$ of the milk gel. Gel strength was measured using a TA-XT2 texture analyzer. Addition of disodium citrate or EDTA resulted in an increase in LT. The addition of Ca-chelating agents also influenced the gelation times and viscoelastic properties of milk gels. The addition of citrate and EDTA, which at $\mathrm{pH} 5.5$ caused increased serum casein, gave a large decrease in gel strength at this $\mathrm{pH}$ value. 

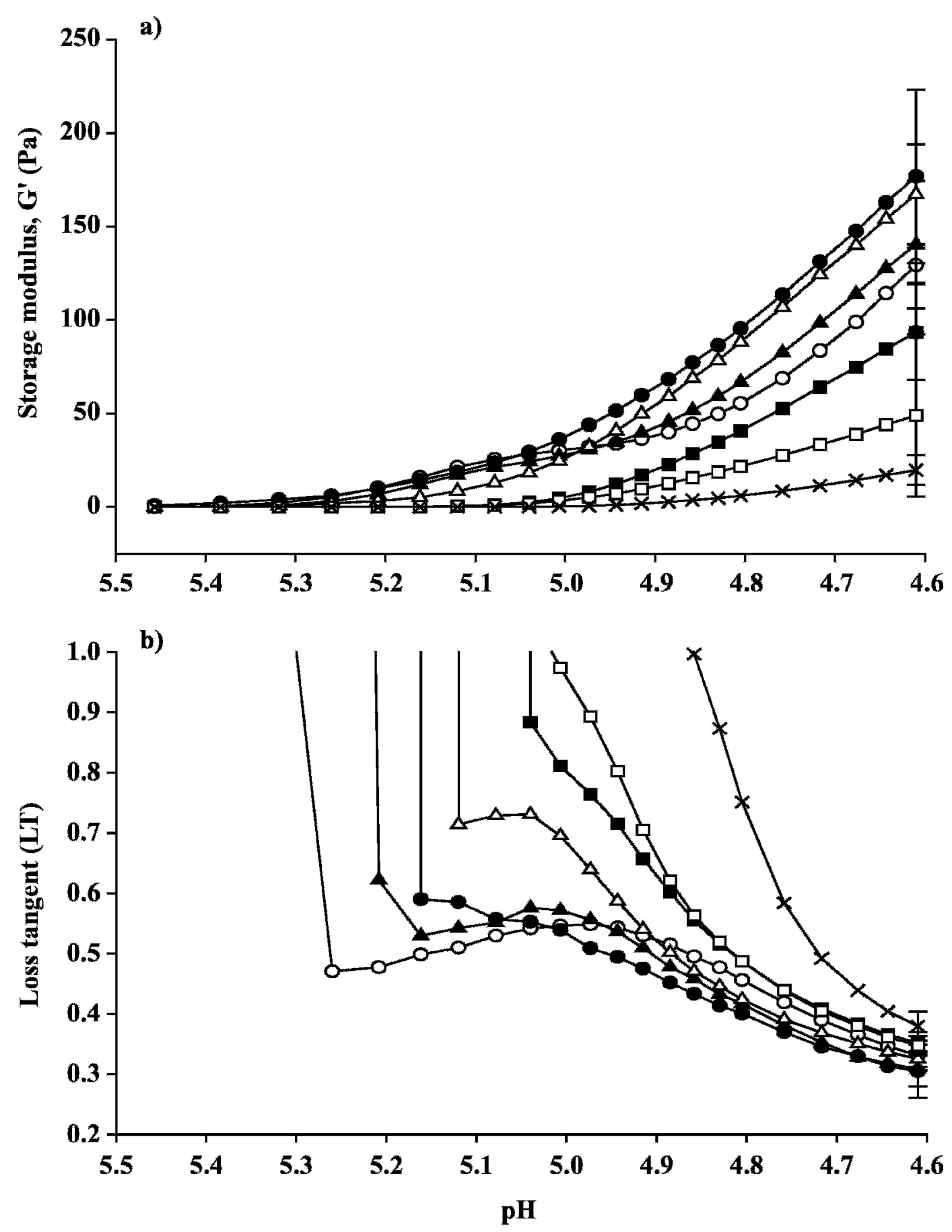

Figure 2. Storage modulus $\left(\mathrm{G}^{\prime}\right)(\mathrm{a})$ and loss tangent (LT) (b) as function of pH for yogurts made from milk with $0(\mathrm{O}), 5(\mathbf{\Delta}), 10(\mathbf{\bullet}), 20$ $(\triangle), 25(\square), 30(\square)$, and $40 \mathrm{mM}(\times)$ added trisodium citrate. Means of triplicates, error bars indicate SD.

However, at lower $\mathrm{pH}$ values gel strength was increased. In acid-heat induced gels at $\mathrm{pH}$ 5.5, the addition of $\mathrm{Na}_{2} \mathrm{HCit}$ or $\mathrm{Na}_{2} \mathrm{H}_{2} \mathrm{EDTA}$, which decrease the CCP content, caused an increase in LT.

The large deformation rheological properties for yogurts are shown in Table 1 . The addition of TSC had a significant effect $(P<0.05)$ on $\sigma_{\text {yield }}$ and $\gamma_{\text {yield }}$ values of yogurt. The highest $\sigma_{\text {yield }}$ value was observed for yogurt made with $10 \mathrm{~m} M$ TSC. The addition of $>10 \mathrm{~m} M$ TSC to milk resulted in a significant reduction in the $\sigma_{\text {yield }}$ of yogurt compared with yogurt without TSC. Lee and Lucey (2004b) found that yogurt gels with large pores 


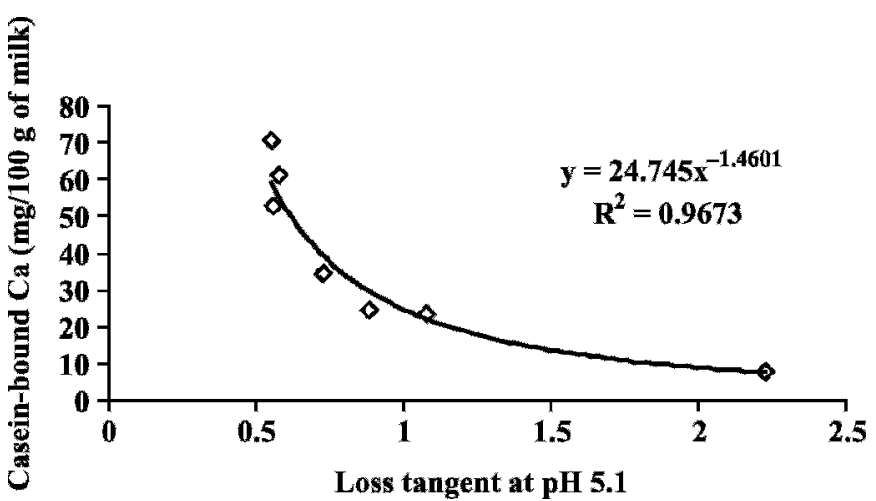

Figure 3. Relationship between the removal of casein-bound $\mathrm{Ca}$ from micelles and the loss tangent value at $\mathrm{pH} 5.1$ in yogurt gels made from these trisodium citrate (TSC)-treated milks. Values are means of triplicates.

and weaker $\mathrm{G}^{\prime}$ values usually had lower $\sigma_{\text {yield }}$ values. The number of bonds per cross section of the strands, strength of bonds, and curvature of the strands affects the large deformation properties of gels (van Vliet et al., 1991; Lucey et al., 1997a).

\section{Whey Separation}

The levels of whey separation in yogurts made with different levels of TSC are shown in Figure 4. Whey separation was significantly lower in gels made with 5 and $10 \mathrm{~m} M$ TSC compared with yogurts without TSC; the lowest whey separation level was observed for gels made with $20 \mathrm{~m} M$ TSC. Higher TSC levels $(>20 \mathrm{mM})$ resulted in significantly $(P<0.05)$ increased whey separation (Figure 4). It appeared that low levels of solubilization of CCP (caused by the use of 5 to $20 \mathrm{~m} M$ of TSC)

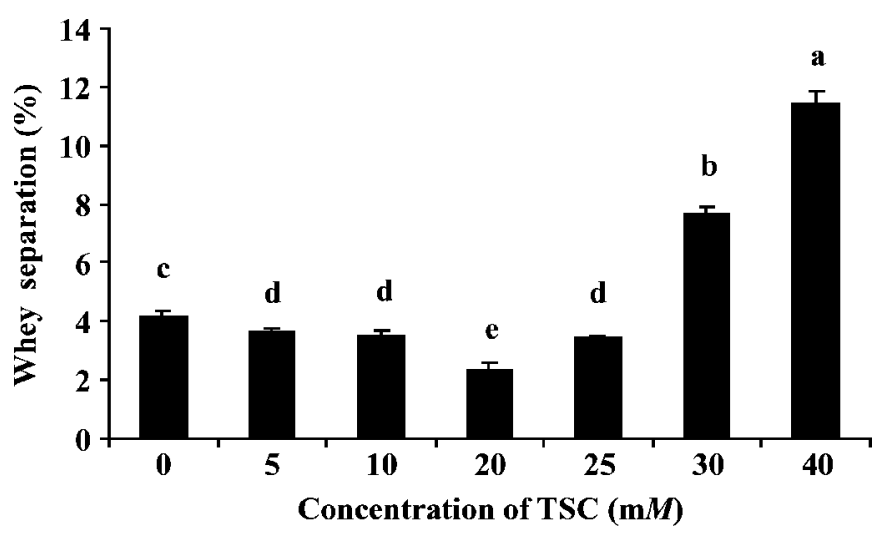

Figure 4. Whey separation of yogurts made from milk with different levels of trisodium citrate (TSC). Whey separation was measured when gels reached at $\mathrm{pH}$ 4.6. Means of triplicates, error bars indicate SD. ${ }^{a-e}$ Columns with different letters are significantly different $(P$ $<0.05)$. reduced whey separation due to increased molecular mobility (as indicated by the increased LT values) and enhanced number of casein interactions (as indicated by the increased $\mathrm{G}^{\prime}$ values).

Whey separation is related to an unstable gel network and excessive rearrangements of a weak gel network (Lucey, 2001). High levels of TSC $\geq 20 \mathrm{~m} M$ may cause disruption of micelle and the excessive loss of CCP crosslinks between caseins. The high levels of whey separation in yogurts with high levels of added TSC were probably related to the low $\mathrm{G}^{\prime}$, low $\sigma_{\text {yield }}$, and high LT values of these gels. Lee and Lucey (2004a) also found that weak yogurt gels (low $\mathrm{G}^{\prime}$, high LT, and low $\sigma_{\text {yield }}$ values) have a less stable network that contains large pores and exhibits high levels of whey separation.

\section{Microstructure}

The microstructure of yogurt gels made from milk with various levels of added TSC is shown in Figure 5. Yogurt gels with 0,5 , or $10 \mathrm{mM}$ TSC (Figure 5a,b,c) were similar with small pores and thin strands. Gels made with $20 \mathrm{~m} M$ TSC had much larger strands (Figure $5 \mathrm{~d}$ ) in agreement with the high $\mathrm{G}^{\prime}$ value at $\mathrm{pH} 4.6$ (Table 1). Higher TSC levels resulted in a progressive increase in apparent pore size and less interconnectivity between strands. These trends are in agreement with the whey separation results (Figure 4). Yogurt gels treated with $40 \mathrm{~m} M$ TSC had very large pores and very little interconnectivity (Figure 5g) in agreement with their very low values for $\mathrm{G}^{\prime}$ and $\sigma_{\text {yield }}$ and high $\mathrm{LT}$ values (Table 1). Unsuccessful attempts were made to measure gel permeability (related to porosity); yogurt gels did not stick well to the glass tubes used in this method (results not shown).

\section{CONCLUSIONS}

The gelation characteristics of yogurts were significantly affected by the level of TSC. The addition of TSC to milk appears to result in 2 different effects depending on TSC concentration. Firstly, at low TSC concentrations $(\leq 10 \mathrm{mM})$, gelation time, $\mathrm{pH}$ at gelation, and LT value were not significantly different from yogurt made without TSC. However, gels made with 10 or $20 \mathrm{mM}$ TSC had the highest $\mathrm{G}^{\prime}$ values at $\mathrm{pH} 4.6$, and gels made with $10 \mathrm{~m} M$ TSC had the highest $\sigma_{\text {yield }}$ value. High TSC levels $(>20 \mathrm{~m} M)$ resulted in a decrease in the $\mathrm{G}^{\prime}$ values at $\mathrm{pH} 4.6$, gelation $\mathrm{pH}, \sigma_{\text {yield }}$, and $\gamma_{\text {yield }}$. At higher TSC concentrations no buffering peak was observed at $\mathrm{pH}$ $\sim 5.1$ during acid titration. The loss of the buffering peak at $\mathrm{pH} \sim 5.1$ was due to the solubilization of CCP from the casein micelles. The solubilization of CCP by TSC disrupted the structure of casein micelles. At low levels 

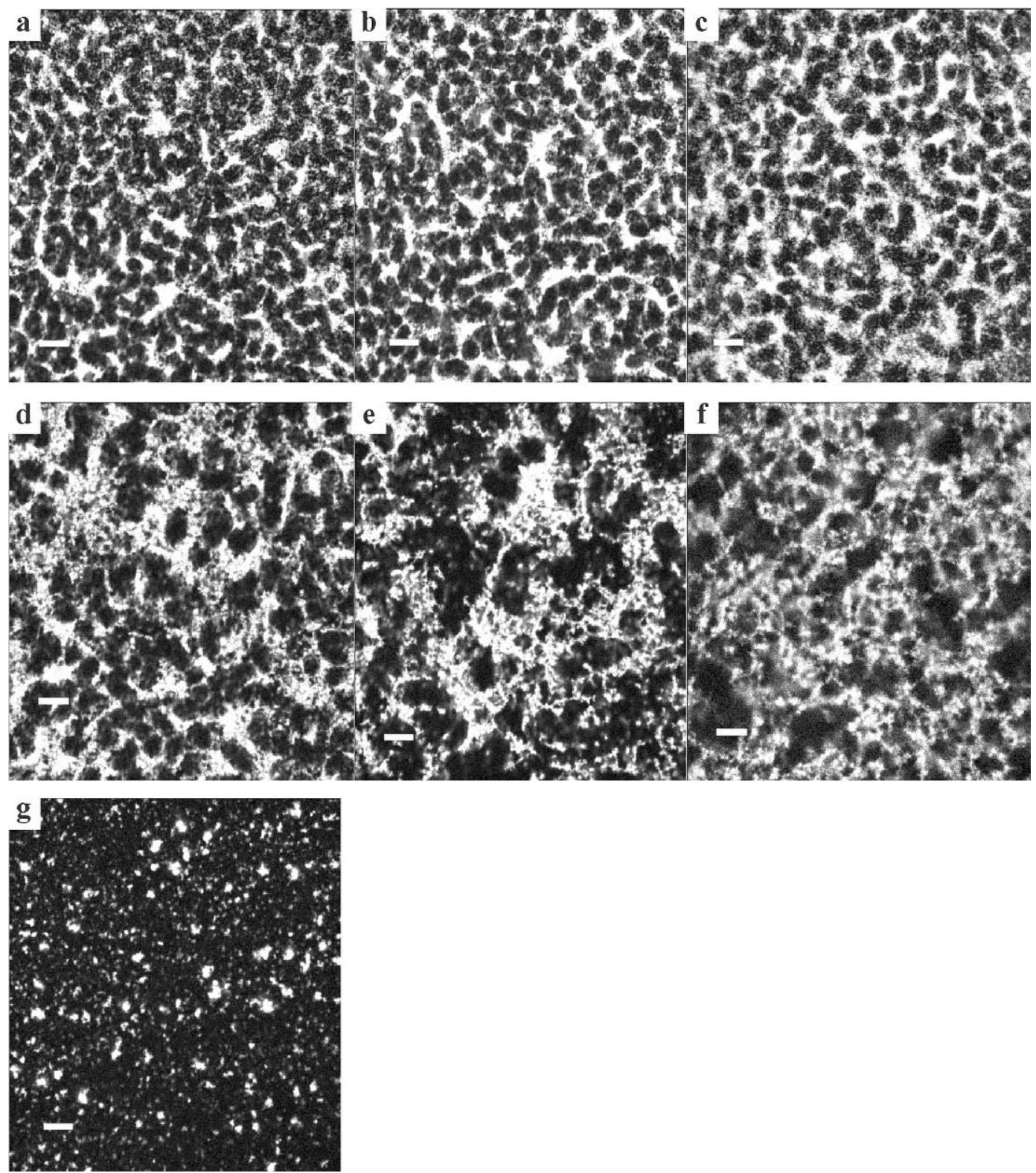

Figure 5. Microstructure of yogurt gels made from milk treated with 0 (a), 5 (b), 10 (c), 20 (d), 25 (e), 30 (f), or 40 (g) mM trisodium citrate (TSC). Yogurt gels were formed at $42^{\circ} \mathrm{C}$ and examined at $\mathrm{pH} 4.6$. The protein matrix is white and pores are dark. Scale bar $=20 \mu \mathrm{m}$.

of CCP removal there was increased molecular flexibility, which indirectly increased gel stiffness due to the enhanced formation of crosslinks between strands. However, when most CCP was removed, the micelles were dispersed and gel properties deteriorated. With high levels of TSC the network character became very mobile (as indicated by the high LT), but the rate of bond formation was low (as indicated by the low $\mathrm{G}^{\prime}$ ) due to loss of CCP crosslinks and casein dispersion. This study demonstrated solubilization of CCP was responsible for the LT maximum in gels made from heated milk because the removal of CCP removed this LT maximum.

At the present time, sodium citrate is listed as an ingredient in several commercial yogurts sold in the United States. Sodium citrate is a permitted ingredient in flavored yogurt (and other dairy-based desserts) according to the Codex Alimentarius standards for food additives (with the guidance of usage under the conditions of good manufacturing practice; Codex Alimentarius, 2005). Trisodium citrate also has a long history of use in dairy products, such as processed cheese. 
It therefore seems possible the TSC could be used as an ingredient in flavored yogurt to improve the textural properties and reduce whey separation.

\section{REFERENCES}

Augustin, M. A. 2000. Mineral salts and their effect on milk functionality. Aust. J. Dairy Technol. 55:61-64.

Bradley, R. L., E. Arnold, D. M. Barbano, R. G. Semerad, D. E. Smith, and B. K. Vines. 1992. Chemical and physical methods. Pages 433-531 in Standard Methods for the Examination of Dairy Products. 16th ed. R. T. Marshall, ed. Am. Public Health Assoc., Washington, DC.

Chandan, R. C., C. H. White, and Y. H. Hui. 2006. Manufacturing Yogurt and Fermented Milks. Blackwell, Ames, IA.

Codex Alimentarius. 2005. Codex General Standard for Food Additives (GSFA) Online Database. Dairy-based desserts (e.g., pudding, fruit or flavoured yoghurt) (Food Category 01.7). http:// www.codexalimentarius.net/gsfaonline/index.html Accessed August 16, 2006.

Dalgleish, D. G., and A. J. R. Law. 1989. pH-induced dissociation of bovine casein micelles II. Mineral solubilization and its relation to casein release. J. Dairy Res. 56:727-735.

De la Fuente, M. A. 1998. Changes in the mineral balance of milk submitted to technological treatments. Trends Food Sci. Technol. 9:281-288.

Esteves, C. L. C., J. A. Lucey, D. B. Hyslop, and E. M. V. Pires. 2003. Effect of gelation temperature on the properties of skim milk gels made from plant coagulants and chymosin. Int. Dairy J. 13:877-885.

Fox, P. F., and D. M. Mulvihill. 1982. Milk proteins: Molecular, colloidal and functional properties. J. Dairy Res. 49:679-693.

Gaucheron, F. 2005. The minerals of milk. Reprod. Nutr. Dev. 45:473-483.

Goddard, S. J., and M. A. Augustin. 1995. Formation of acid-heat induced skim milk gels in the $\mathrm{pH}$ range 5.0-5.7: Effect of the addition of salts and calcium chelating agents. J. Dairy Res. 62:491-500

Griffin, M. C. A., R. L. Lyster, and J. C. Price. 1988. The disaggregation of calcium-depleted micelles. Eur. J. Biochem. 174:339-343.

Horne, D. S. 1998. Casein interactions: Casting light on the black boxes, the structure in dairy products. Int. Dairy J. 9:261-268.

Johnston, D. E., and R. J. Murphy. 1992. Effects of some calcium chelating agents on the physical properties of acid-set milk gels. J. Dairy Res. 59:197-208.

Kristo, E., C. G. Biliaderis, and N. Tzanetakis. 2003. Modelling of the acidification process and rheological properties of milk fermented with a yogurt starter culture using response surface methodology. Food Chem. 83:437-446.

Lee, W. J., and J. A. Lucey. 2004a. Rheological properties, whey separation, and microstructure in set-style yogurt: Effects of heating temperature and incubation temperature. J. Texture Stud. 34:515-536.

Lee, W. J., and J. A. Lucey. 2004b. Structure and physical properties of yogurt gels: Effect of inoculation rate and incubation temperature. J. Dairy Sci. 87:3153-3164.

Lin, S. H. C., S. L. Leong, R. K. Dewan, V. A. Bloomfield, and C. V. Morr. 1972. Effect of calcium ion on the structure of native bovine casein micelles. Biochemistry 11:1818-1821.

Lucey, J. A. 2001. The relationship between rheological parameters and whey separation in milk gels. Food Hydrocoll. 15:603-608.

Lucey, J. A. 2002. Formation and physical properties of milk protein gels. J. Dairy Sci. 85:281-294.

Lucey, J. A., C. Gorry, B. O'Kennedy, M. Kalab, R. Tan-Kinita, and P. F. Fox. 1996. Effect of acidification and neutralization of milk on some physico-chemical properties of casein micelles. Int. Dairy J. 6:257-272.
Lucey, J. A., B. Hauth, and P. F. Fox. 1993. The acid-base buffering properties of milk. Milchwissenschaft 48:268-272.

Lucey, J. A., P. A. Munro, and H. Singh. 1998a. Whey separation in acid skim milk gels made with glucono- $\delta$-lactone: Effects of heat treatment and gelation temperature. J. Texture Stud. 29:413426.

Lucey, J. A., M. Tamehana, H. Singh, and P. A. Munro. 1998b. A comparison of the formation, rheological properties and microstructure of acid skim milk gels made with a bacterial culture or glucono- $\delta$-lactone. Food Res. Int. 31:147-155.

Lucey, J. A., M. Tamehana, H. Singh, and P. A. Munro. 1998c. Effect of interactions between denatured whey proteins and casein micelles on the formation and rheological properties of acid skim milk gels. J. Dairy Res. 65:555-567.

Lucey, J. A., C. T. Teo, P. A. Munro, and H. Singh. 1997a. Rheological properties at small (dynamic) and large (yield) deformations of acid gels made from heated milk. J. Dairy Res. 64:591-600.

Lucey, J. A., T. van Vliet, K. Grolle, T. Geurts, and P. Walstra. 1997b. Properties of acid casein gels made by acidification with glucono$\delta$-lactone. 1. Rheological properties. Int. Dairy J. 7:381-388.

Mizuno, R., and J. A. Lucey. 2005. Effects of emulsifying salts on the turbidity and calcium phosphate-protein interactions in casein micelles. J. Dairy Sci. 80:3070-3078.

Mohammad, K. S., and P. F. Fox. 1983. Influence of some polyvalent organic acids and salts on the colloidal stability of milk. J. Soc. Dairy Technol. 36:112-117.

Morr, C. V. 1967. Some effects of pyrophosphate and citrate ions upon the colloidal caseinate-phosphate micelles and ultrafiltrate of raw and heated skim milk. J. Dairy Sci. 50:1038-1044.

Munyua, J. K., and M. Larsson-Raznikiewicz. 1980. The influence of $\mathrm{Ca}^{2+}$ on the size and light scattering properties of casein micelles. 1. $\mathrm{Ca}^{2+}$ removal. Milchwissenschaft 35:604-606.

Park, Y. W. 2000. Comparison of mineral and cholesterol composition of different commercial goat milk products manufactured in USA. Small Rumin. Res. 37:115-124.

Raphaelides, S. N., and A. Gioldasi. 2005. Elongational flow studies of set yogurt. J. Food Eng. 70:538-545.

Tamime, A. Y. 2006. Fermented Milks. Blackwell, Oxford, UK.

Tamime, A. Y., and R. K. Robinson. 1999. Yoghurt: Science and Technology. 2nd ed. CRC Press, Boca Raton, FL.

Udabage, U., I. R. McKinnon, and M. A. Augustin. 2000. Mineral and casein equilibria in milk: Effect of added salts and calciumchelating agents. J. Dairy Res. 67:361-370.

Udabage, U., I. R. McKinnon, and M. A. Augustin. 2001. Effects of mineral salts and calcium chelating agents on the gelation of renneted skim milk. J. Dairy Sci. 84:1569-1575.

van Hooydonk, A. C. M., H. G. Hagedoorn, and I. J. Boerrigter. 1986. $\mathrm{pH}$-induced physico-chemical changes of casein micelles in milk and their effect on renneting. I. Effect of acidification on physicochemical properties. Neth. Milk Dairy J. 40:281-296.

van Vliet, T., H. J. M. van Dijk, P. Zoon, and P. Walstra. 1991. Relation between syneresis and rheological properties of particle gels. Colloid Polym. Sci. 269:620-627.

Visser, J., A. Minihan, P. Smits, S. B. Tjan, and I. Heertje. 1986. Effects of $\mathrm{pH}$ and temperature on the milk salt system. Neth. Milk Dairy J. 40:351-368.

Walstra, P. 1990. On the stability of casein micelles. J. Dairy Sci. 73:1965-1979.

Ward, B. R., S. J. Goddard, M. A. Augustin, and I. R. McKinnon. 1997. EDTA-induced dissociation of casein micelles and its effect on foaming properties of milk. J. Dairy Res. 64:495-504.

White, J. C. D., and D. T. Davies. 1958. The relation between the chemical composition of milk and the stability of the caseinate complex. I. General introduction, description of samples, methods and chemical composition of samples. J. Dairy Res. 25:236-255.

Zoon, P., T. van Vliet, and P. Walstra. 1988. Rheological properties of rennet-induced skim milk gels. 1. Introduction. Neth. Milk Dairy J. 42:249-269. 